\title{
ARTIKKELIT
}

\section{ע Puolisohoitajan henkilökohtainen kasvu}

\author{
Tiina Autio ${ }^{1}$ ja Sari Rissanen ${ }^{2}$ \\ ${ }^{1}$ Pääkaupunkiseudun sosiaalialan osaamiskeskus Socca \\ ${ }^{2}$ Itä-Suomen yliopisto, ybteiskuntatieteiden ja kauppatieteiden tiedekunta
}

\begin{abstract}
Omaishoitajat pitävät huolta ikääntyneistä, vammaisista tai sairastuneista läheisistään ja tekevät osaltaan heille mahdolliseksi asua kotona. Monet omaishoitajat ovat itse ikääntyneitä ja pitävät huolta ikääntyneestä puolisostaan. Tässä artikkelissa analyysin kohteena on puolisohoitajan henkilökohtainen kasvu puolisohoitajan kokemana. Analyysissa tarkastellaan kirjallisuudessa esille tulleita tulkintoja puolisohoitajan kasvun kokemuksista. Tutkimusmenetelmänä on kirjallisuuskatsauksessa koottujen artikkeleiden sisällönanalyysi.

Kirjallisuuskatsauksen perusteella henkilökohtainen kasvu puolisohoidossa ilmenee kokemuksina, kuten ihmissuhteiden ja elämän arvostamisena, uusien taitojen löytämisenä ja henkilökohtaisena vahvistumisena. Ihmissuhteet tuntuvat entistä tärkeämmiltä ja merkityksellisemmiltä, mikä ilmenee myös myötätuntona muita kohtaan. Myös suhde kuolemaan osana elämää nousee esille. Kasvu saattaa tulla näkyviin myös elämälle asetettujen tavoitteiden muuttumisena, positiivisina hoivakokemuksina sekä elämään liittyvien positiivisten asioiden havaitsemisena. Kasvuun liittyy myös kokemus uusien asioiden ja taitojen oppimisesta, mikä vahvistaa luottamusta omaan selviytymiseen. Tässä tutkimuksessa tarkastelun kohteena olivat kasvun kokemusten tulkinnat kirjallisuudessa, mutta lisätutkimusta kaivataan erityisesti prosesseista ja keinoista, joiden kautta kasvun kokemuksia saavutetaan.
\end{abstract}

\section{Johdanto}

Omaisten tekemällä hoivatyöllä on suuri merkitys sosiaali- ja terveydenhoidon palvelujärjestelmälle ja koko yhteiskunnalle; se mahdollistaa taloudellisesti ja inhimillisesti arvokkaan hoivan tuen tarpeessa oleville henkilöille. Jo useiden vuosien ajan on tehty lukuisia omaishoitoon liittyviä selvityksiä ja omaishoitajaa tukeva palvelutoiminta on ollut aktiivisen kehittämisen kohteena. Omaishoidon yhteiskunnal- lisesta ja inhimillisestä merkityksestä johtuen pidetään erityisen tärkeänä kehittää vaikuttavia toimintatapoja, joilla tuetaan omaishoitajien jaksamista. (esim. Noro 2019.)

Omaishoidon tutkimuksen painopiste on aiemmin ollut paljolti omaishoitoon liittyvän uupumuksen ja haasteiden tutkimuksessa sekä myös omaishoitoon liittyvissä kielteisissä kokemuksissa, elämänmuutoksissa ja selviytymisstrategioissa (McLennon, Habermann \& Rice 2011; Quinn, Clare \& Woods 2010; Noyes 
ym. 2010; Lazarus \& Folkman 1984; Pearlin, Mullan, Semple \& Skaff 1990; Mackenzie \& Greenwood 2012). Viime vuosina on kuitenkin tehty yhä enemmän tutkimusta myös omaishoitoon liittyvistä positiivisista kokemuksista (mm. Mackenzie \& Greenwood 2012).

Tämä artikkeli sitoutuu näiden positiivisten kokemusten tutkimukseen (Fredrickson 2001; Fredrickson \& Cohn 2010; Seligman 2002; Seligman 2011). Esimerkiksi Folkman (2008) korostaa, että positiivisilla tunteilla on tärkeä rooli stressiin liittyvässä prosessissa. On tärkeä tarkastella lähemmin niiden merkitystä omaishoidossa eteen tulevissa haasteellisissa tilanteissa. Eri tutkimuksissa on tuotu esille, että ihmisten kannattaa viljellä positiivisia tunteita yleisesti tunne-elämässään, mutta reagoida elämässä eteen tuleviin merkitseviin tapahtumiin ja tilanteisiin niihin luontaisesti soveltuvilla tunteilla. On esimerkiksi todettu, että negatiiviseksi määritellyillä tunteilla ja niihin liittyvillä fysiologisilla reaktioilla on tärkeä merkitys arkea uhkaavissa elämäntilanteissa ja kohdattaessa vakavia menetyksiä $(\mathrm{mm}$. Kashdan \& Biswas-Diener 2015). Lisätutkimusta tarvitaan kuitenkin erityisesti niistä prosesseista, keinoista ja tukemisen muodoista, joiden avulla omaishoitajat voivat kohdata ja käydä läpi omaishoitoon liittyviä väistämättömiä menetyksiä ja luopumisia ja samalla kokea merkityksellisyyden ja onnistumisen kokemuksia.

Kirjoittajien (Autio \& Rissanen 2018) puolisoaan hoitavan positiivisia tunteita käsittelevässä kirjallisuuskatsauksessa tarkasteltiin puolisohoitajien kokemia positiivisia tunteita. Näihin liittyen nousi esille useita käsitteitä, kuten resilienssi (resilience), hyödyn löytäminen (beneft-finding), merkityksen löytäminen (finding meaning), henkilökohtainen kasvu (personal growth) ja trauman jälkeinen kasvu (post-traumatic growth). Tässä artikkelissa edellä mainituista käsitteistä syvemmän tarkastelun kohteeksi valittiin kasvun käsite. Artikkelissa avataan myös kasvun kokemusten merkitystä puolisoaan hoitavan henkilön jaksamiselle ja palvelujärjestelmälle.

\section{Miksi tutkia henkilökohtaista kasvua omaishoidossa?}

Tedeschi ja Calhoun (2004) märrittelevät trauman jälkeisen kasvun (post traumatic growth, $P T G$ ) seurauksena stressaavassa tilanteessa kamppailusta. Kasvulla ei tarkoiteta paluuta perustilaan vaan enemmänkin paremman pysyvän tilan saavuttamista. Omaishoitotilanteisiin liittyy paljon stressiä aiheuttavia kokemuksia, joten on perusteltua tutkia omaishoitajan kokemuksia kasvusta (mm. Cadell 2007).

Tedeschin ja Calhounin mukaan elämänkriisit toimivat monille ihmisille katalysaattoreina parantuneille henkilökohtaisille tai sosiaalisille resursseille, parantuneille selviytymistaidoille tai henkisille oivalluksille. Parantuneet henkilökohtaiset resurssit voivat merkitä assertiivisuutta, kypsyyttä tai itselle tärkeiksi koettujen asioiden muutoksia ja parantuneet sosiaaliset resurssit taas parantuneita suhteita ystäviin ja perheeseen. Selviytymistaitojen kohentuminen voi näkyä erityisesti haasteellisia ja ongelmallisia tilanteita kohdattaessa (Tedeschi \& Calhoun 2004; Findler, Dayan-Sharabi \& Yaniv 2014).

Trauman jälkeisen kasvun kanssa rinnakkain käytetään henkilökohtaisen kasvun käsitettä (personal growth) (mm. Findler ym. 2014). Myös kirjallisuuskatsauksen hakusanana 'personal growth' tuottaa osittain samoja tutkimuksia kuin hakusana 'post traumatic growth'.

Omaishoitoon sisältyvistä stressitilanteista osa on odottamattomia ja yllättäviä, osa taas enemmän ennakoitavissa olevia. Tutkimuksissa on tuotu esille, että silloin kun elämässä eteen tuleva haaste on normatiivinen, yleisesti koettu, lyhyt kestoltaan ja odotettavissa oleva, selviytymiskeinojen sisältö eroaa merkittävästi verrattuna haasteeseen, joka on ei-normatiivinen, kestoltaan ei-rajattu ja odottamaton (Kling, Malick-Seltzer \& Ryff 1997, Hamana \& Sharon 2013, 1720 mukaan). Esimerkiksi puolison äkilliseen ja vakavaan sairastumiseen tai vammautumiseen liittyvä omaishoidon alku on monille yllättävä ja järkyttävä tilanne, joka ai- 
heuttaa omaishoitajalle huolta ja josta selviytyminen haastaa paljon hänen voimavarojaan ja johon sopeutuminen vie aikaa. Myös hoivaa tarvitsevan läheisen sairauden uusiutuminen tai eteneminen voi järkyttää omaishoitajaa ja vähentää luottamusta tulevaan.

Yleisesti omaishoidossa stressaavat tilanteet aiheutuvat runsaasta joukosta yksittäisiä tai toistuvia vaatimuksia. Näitä synnyttävät sekä läheisen avustaminen päivittäisissä toimissa ja hoivan tarpeissa että selviytyminen hänen sairauteensa tai vammaansa liittyvistä kognitiivisista, fyysistä, psyykkisistä ja sosiaalisista rajoituksista ja ongelmista. Näiden primaareiksi stressitekijöiksi nimettyjen asioiden lisäksi omaishoivalla voi olla monia vaikutuksia hoitoa tarvitsevan läheisen ja omaishoitajan väliseen suhteeseen, perhesuhteisiin sekä muihin elämän alueisiin, kuten omaishoitajan työelämään, sosiaaliseen elämään ja harrastuksiin. Primaarit stressitekijät voivat siten vaikuttaa negatiivisesti omaishoitajaan ja johtaa sekundaarisiin rooleihin liittyviin tai sisäisiin ristiriitoihin. Ristiriidat taas voivat olla yhteydessä omaishoitajan itseluottamukseen ja selviytymisen kokemuksiin (Gottlieb \& Wolfe 2002, 325; Montgomery \& Williams 2001, 24; Mullan 1992, 673; Autio 2014). Näillä kaikilla muutoksilla on syvälle arkeen meneviä vaikutuksia ja niihin liittyvän surun ja luopumisen läpikäyminen voi avata puolisoaan hoitavalle henkilökohtaisen kasvun kokemuksia (Ott, Sanders \& Kelber 2007, 798).

\section{Miksi tutkia käsitteen piirteitä?}

Käsitteillä on tärkeä rooli tiedon kehittymisessä. Käsitteet ovat myös keskeisiä jokapäiväisessä olemisessa ja vuoropuhelussa. Käsitteet auttavat meitä pitämään ympäristöstä tulevat ärsykkeet ymmärrettävinä. Silloin kun käsitteen määritelmä tai käsitteen ominaisuudet ovat epäselviä, sen mahdollisuudet olla apuna vuoropuhelussa heikkenevät. Epäselvät käsitteet voivat johtaa kommunikaation epäonnistumiseen, kun yksilöiden tulkinnat käsitteistä vaihtelevat tai ovat satunnaisia (Rodgers 1989, 14, 330-335; Walker \& Avant 2005; Chinn \& Jacobs 1992,393). Käsitteitä voidaan pitää teorian rakennusosina, joten niiden analyysillä on olennainen merkitys teorianmuodostuksessa ja teorioiden kehittämisessä (Jacobs \& Huether 1992, 524).

Käsiteanalyysin tekemisen tapoja on monenlaisia, kuten esimerkiksi historiallinen ja tulkitseva käsiteanalyysi (Lämsä \& Takala 2004; Puusa 2008). Tässä artikkelissa ei tehdä varsinaista käsiteanalyysiä henkilökohtaisesta kasvusta vaan analysoidaan aikaisemman tutkimuksen pohjalta henkilökohtaiseen kasvuun liitettyjä kategorioita. Tällöin lähestytään Walkerin ja Avantin (2005) esittelemää tapaa, jossa tavoitteena on selkeyttää, tarkentaa ja tutkia käsitteiden piirteitä ja ominaisuuksia. Näin analyysissä hyödynnetään osaa käsiteanalyysiin liitetyistä vaiheista, jotka tässä ovat: 1) käsitteen valinta (ks. edellinen luku), 2) analyysin tavoitteiden määrittely (ks. seuraava luku), 3) ominaispiirteiden tunnistaminen kirjallisuudesta. (ks. Walker ja Avant 2005).

\section{Tutkimuskysymykset ja kirjallisuuskatsaus}

Tämän artikkelin tavoitteena on sisällönanalyysin keinoin selvittää puolisoaan hoitavan henkilön henkilökohtaista kasvua tarkastelemalla niitä tulkintoja, joita tieteellisessä kirjallisuudessa on esitelty.

Analyysin aineistona on käsitteeseen liittyvä tieteellinen kirjallisuus, joka koottiin keskeisistä kansainvälisistä artikkelitietokannoista noin viiden viimeisen vuoden ajalta (taulukko 1). Hakujen avaintermit olivat 'personal growth', 'posttraumatic growth', 'spouse caring' ja 'caring for a spouse' sekä näiden yhdistelmät. Muut hakukriteerit olivat: vertaisarvioitu artikkeli, aikajänne 2014-2018, koko teksti ja englannin kieli. 
Taulukko 1. Elektronisten hakujen tietokannat

\begin{tabular}{|l|l|}
\hline Hakukriteerit & Tietokanta \\
\hline Avaintermit: & 1. MEDLINE/PubMed (NLM) \\
- 'personal growth' & 2. OneFile (GALE) \\
- 'spoustraumatic growth' & 3. Health Reference Center Academic (Gale) \\
- 'caring for a spouse' & 4. Sage Journals (Sage Publications) \\
- em. termien yhdistelmät & 5. ABI/INFORM Complete \\
Muut hakukriteerit: & 6. ABI/INFORM Global \\
- vertaisarvioitu artikkeli & 7. SpringerLink, PMC (PubMed Central) \\
- aikajänne 2014-2018 & 8. Scopus \\
- koko teksti & 9. ScienceDirect Journals (Elsevier) \\
- englannin kieli & 10. Sage Publications (CrossRef) \\
& 11. Springer (CrossRef) \\
& 12. Directory Of Open Access Journals (DOAJ) \\
& 13. Taylor \& Francis Online - Journals \\
& 14. Informa - Taylor \& Francis (CrossRef) \\
& 15. Oxford Journals (Oxford University Press) \\
& 16. Oxford University Press (CrossRef) \\
& 17. ERIC (U.S. Dept of Education) \\
18. Academic Law Reviews (LegisNexis) & 19. Emerald Insight, CBCA Complete \\
& 20. Medknow Publications \\
& 21. Social Sciences Citation Index (Web of Science) \\
& 22. Science Citation Index Expanded \\
23. ProQuest Pharma Collection \\
24. Neurosciences Abstracts \\
25. Sociological Abstracts ja Elsevier (CrossRef)
\end{tabular}

Kasvun kokemuksia arvioitiin kahden tutkimuskysymyksen avulla, sillä aineistossa oli useita tutkimuksia, joissa käytettiin erillistä mittaria kasvun kokemusten arviointiin. Tutkimuskysymykset olivat:

1) Millaisia henkilökohtaisen kasvun tulkintoja on sisällytetty mittareihin, joilla mitataan puolisoaan hoitavan henkilökohtaista kasvua?

2) Millaisia muita tulkintoja on löydettävissä puolisoaan hoitavan henkilökohtaisesta kasvusta?

Ensimmäisellä tutkimuskysymyksellä tarkasteltiin erityisesti käytettyjen mittareiden henkilökohtaista kasvua mittaavia ulottuvuuksia. Toisen tutkimuskysymyksen tavoitteena oli tuoda rikkaampaa sisältöä löydettyihin kasvun ulottuvuuksiin sekä tarkastella, löytyykö kas- vulle muita tulkintoja kuin mittareita tarkasteltaessa oli löydettävissä.

Alkuperäisissä kirjallisuushauissa löytyi yhteensä 976 (hakusanalla personal growth) ja 138 (hakusanalla postraumatic growth) artikkelia, joista osa oli samoja. Näistä alustavaan tarkasteluun valikoitui yhteensä 156 artikkelia sen perusteella, että niissä oli mainittu kasvun käsite. Varsinaiseen käsiteanalyysiin valikoitui 20 artikkelia. Valikoitumisen perusteena oli se, että artikkelissa kuvattiin tutkimuksen kohteena olevan kasvun käsitteen tulkintoja. Artikkelit, joissa kasvun käsitettä ei juuri kuvattu, joissa ei ollut omaa empiiristä aineistoa tai joissa ei ollut lainkaan puolisohoitoa kuvaavaa empiiristä aineistoa, rajattiin aineiston ulkopuolelle. Kokonaisuudessaan tehty kirjallisuuskatsaus oli narratiivinen eikä kirjallisuushaussa noudatettu systemaattisen kirjallisuuskatsauksen kriteerejä. 
Tähän katsaukseen valituista 20 artikkeleista kuusi (6/20) oli lähtöisin Pohjois-Amerikan alueelta: viisi Yhdysvalloista ja yksi Kanadasta. Viisi artikkelia (5/20) oli Aasian maista: kaksi Kiinasta, kaksi Japanista ja yksi Turkista. Loput yhdeksän (9/20) olivat Euroopan alueelta: neljä Iso-Britanniasta, yksi Tanskasta, yksi Irlannista, yksi Sveitsistä, yksi Hollannista ja yksi Italiasta.

Omaishoidon syy vaihteli tutkimuksissa: yhdeksässä tutkimuksessa syynä oli syöpäsairaus, kahdessa krooniset sairaudet ja kolmessa dementia. Muita syitä omaishoitoon olivat selkäydinvaurio, sydämen vajaatoiminta, Parkinsonin tauti, aivohalvaus sekä skitsofrenia. Lisäksi yhdessä tutkimuksessa osalla omaishoi- dettavista oli mielenterveysongelmia ja osalla fyysisiä ongelmia. Monissa katsauksen tutkimuksissa ei eritelty kohdejoukon ikää. Koska tarkastelun kohteena olivat erityisesti puolisohoitajat ja useissa tutkimuksissa omaishoidon syynä oli ikääntymiseen liittyvä sairaus, niin tuloksissa painottuvat erityisesti ikääntyvien henkilöiden kokemukset.

Tutkimusmenetelmänä katsauksen tutkimuksissa oli kolmessatoista kyselytutkimus ja neljässä haastattelu. Lisäksi yhdessä tutkimuksessa menetelmänä oli kysely ja fokusryhmähaastattelu, yhdessä kysely ja haastattelu sekä yhdessä satunnaistettu koeasetelma.

Taulukko 2. Kirjallisuushakujen toimeenpano

\begin{tabular}{|c|c|c|c|}
\hline Hakukriteeri & Haun tuottama & \multicolumn{2}{|c|}{ Kirjallisuuden valinta kaksivaiheisesti } \\
\hline \multirow[t]{2}{*}{$\begin{array}{l}\text { 1. Vertaisarvioitu } \\
\text { 2. Aikajänne } \\
\text { 3. Englannin kieli } \\
\text { 4. Avaintermit }\end{array}$} & \multirow[t]{2}{*}{$\begin{array}{l}\text { - } 976 \text { artikkelia, } \\
\text { hakusanalla personal } \\
\text { growth } \\
\text { - } 138 \text { artikkelia, } \\
\text { hakusanalla } \\
\text { postraumatic growth }\end{array}$} & \multirow[t]{2}{*}{$\begin{array}{l}\text { Artikkelit, joissa } \\
\text { kasvun käsite on } \\
\text { mainittu, } n=156 \text {. }\end{array}$} & $\begin{array}{l}\text { Analyysiaineisto. Artikkelit, joissa on } \\
\text { erityisesti kuvattu kasvun käsitteen } \\
\text { tulkintoja ja joissa oli mukana } \\
\text { puolisoaan hoitavia koskevaa } \\
\text { empiiristä aineistoa, } n=20(7 / 2018 \text {, } \\
3 / 2017,3 / 2016,1 / 2015,6 / 2014)\end{array}$ \\
\hline & & & $\begin{array}{l}\text { Artikkelit, joissa kasvun käsitettä } \\
\text { on kuvattu niukasti tai ei ole omaa } \\
\text { empiiristä tutkimusaineistoa tai } \\
\text { ei ole ollenkaan puolisohoitajia } \\
\text { käsittelevää empiiristä aineistoa } \\
(n=136)\end{array}$ \\
\hline
\end{tabular}

Analyysin tarkoituksena oli selventää henkilökohtaisen kasvun käsitettä puolisoaan hoitavan omaishoidossa. Valitun kahdenkymmenen artikkelin sisällönanalyysin tulokset on kuvattu taulukoissa 3 ja 4. Taulukossa 3 vastataan tutkimuskysymykseen 1 ja siinä on esitelty katsauksen tutkimuksissa esille nousseet kasvun mittaamisessa käytetyt mittarit ja niihin sisälletyt kasvun kategoriat. Taulukossa 4 vastataan tutkimuskysymykseen 2 ja siinä kuvataan sisällöllisesti tarkemmin kategorioita sekä tarkastellaan, löytyykö kirjallisuusaineistosta puolisoaan hoitavan henkistä kasvua kuvaavia muita kategorioita.
Sisällönanalyysi oli osittain deduktiivinen ja teorialähtöinen, osittain induktiivinen (Elo \& Kyngäs 2008; Tuomi \& Sarajärvi 2003). Sisällönanalyysissä ryhmittelyn avuksi valittiin luokittelu, joka pohjautui Tedeschin ja Calhounin (1996; 2004) kehittämän trauman jälkeistä kasvua mittaavan PTGI-mittarin (Post Traumatic Growth Inventory) ulottuvuuksiin. Tämä mittari valikoitui, koska alustavassa tarkastelussa näkyi, että trauman jälkeistä kasvua oli mitattu tutkimusaineistossa useimmiten kyseisellä mittarilla ja se pohjautui Tedeschin ja Calhounin pitkäaikaisiin kasvuun liittyviin tutkimuksiin. Mittarissa on 21 osiota, joita kuvaa- 
vat seuraavat faktorit: suhteet muihin ihmisiin, uudet mahdollisuudet, henkilökohtainen vahvuus, hengellinen muutos ja elämän arvostaminen. Tarkemmin mittaria kuvataan tulosten kuvausten yhteydessä. Tutkimuskysymyksissä 1 ja 2 edellä esitetyt mittarin ulottuvuudet otettiin luokittelun pohjaksi ja niitä täydennettiin induktiivisesti toteutetun sisällönanalyysin tuloksilla.

\section{Tulokset}

\section{Henkilökohtaisen kasvun tulkinnat mittareita käyttäneissä tutkimuksissa}

Kasvun kokemuksia arvioitiin useissa $(n=12)$ katsauksen tutkimuksissa tätä varten kehitettyjen mittareiden avulla. Taulukossa 3 on kuvattu kasvun ala- ja yläkategoriat, jotka nousivat esille mittareita hyödyntäneissä tutkimuksissa.

Tedeschin ja Calhounin (1996) kehittämää PTGI-mittaria (Post Traumatic Growth Inventory) käytti kaikkiaan viisi valituista tutkimuksista (Balaban ym. 2017; Tallman ym. 2014; Hirooka ym. 2018a; Offerman ym. 2015; Cormio ym. 2014). Tällä mittarilla kartoitetaan henkilöiden kokemia positiivisia muutoksia merkittävien stressitekijöiden jälkeen. Mittari sisältää 21 osiota, joiden avulla henkilö itse tekee arvion kokemuksistaan asteikolla 0-6.

PTGI-mittarissa on löydetty muun muassa viisi faktoria: suhteet muihin ihmisiin, uudet mahdollisuudet, henkilökohtainen vahvuus, hengellinen muutos ja elämän arvostaminen. Suhteita muihin ihmisiin kartoittivat esimerkiksi kysymykset ihmissuhteiden parantumisesta, koettu läheisyyden tunne, kyky luottaa muihin ihmisiin, kokemus muiden ihmisten tarpeellisuudesta ja ihmissuhteiden merkityksellisyyden oivaltaminen. Uudet mahdollisuudet taas tarkoittivat esimerkiksi uusien kiinnostuksen kohteiden, uusien polkujen ja ennen tavoittamattomien mahdollisuuksien löytämistä elämässä. Henkilökohtainen vahvuus ilmeni esimerkiksi kokemuksena selviytyä vaikeuk- sista, vahvuuden tunteena ja itsetuntemuksena. Hengelliset muutokset ilmenivät uskon ja hengellisyyden vahvistumisena, elämän arvostaminen tuli esille keskittymisenä tärkeisiin asioihin elämässä ja syvempänä käsityksenä elämän tarkoituksesta. (Tedechi \& Calhoun 1996.)

Brandin ja kumppaneiden (2016) tutkimuksessa käytettiin Parkin, Cohenin ja Murchin (1996) kehittämää SRGS-mittaria (Stress Related Growth Scale). Sen avulla arvioidaan sitä, missä määrin henkilöiden näkökulmat ja käyttäytyminen muuttuvat positiivisesti traumaattisten tapahtumien vaikutuksesta. Henkilö arvioi itse kolmea osa-aluetta, joita ovat sosiaalinen tuki, henkilöiden väliset suhteet ja henkilökohtainen kasvu.

Charlesworthin ja muiden $(2017,2016)$ sekä Künzlerin ja muiden (2014) artikkeleissa henkilökohtaista kasvua arvioitiin Ryffin ja Keyesin kehittämällä PGI-indeksillä (Personal Growth Index). Indeksi pitää sisällään kolme osa-aluetta, joita vastaaja itse arvioi. Nämä ovat yksilöllinen kehittyminen, avoimuus uusille kokemuksille sekä tunne mahdollisuuksista ja kehittymisestä ajan kuluessa (Ryff \& Keyes 1995).

Vastaavasti Mein ja kumppaneiden (2017) tutkimuksessa käytetyssä The Adult Carer Quality of Life -mittarissa painottuivat henkilökohtainen ihmisenä kasvaminen, oppiminen ja kehittyminen sekä positiivisten asioiden kokeminen hoivaamisessa.

Omaishoidossa koettujen hyötyjen arvioimiseen käytettiin mittaria, joka oli nimeltään Benefit Finding Scale (Lum ym. 2014). Mittarissa löydetyt ulottuvuudet olivat perheen ja muiden ihmisten merkityksen oivaltaminen, asioiden hyväksyminen, paremmat selviytymiskeinot ja henkinen vahvistuminen sekä uusien prioriteettien löytäminen. Ihmissuhteiden arvostamista ilmensivät perheenjäsenten välisten suhteiden merkityksen oivaltaminen sekä perheenjäsenten lähentyminen toisiinsa (Lum ym. 2014). Mittarin ulottuvuudet olivat samankaltaisia kuin varsinaisissa kasvun mittareissa, joten tutkimuksen liittäminen kirjallisuuskatsaukseen oli perusteltua. 
Henkilökohtaisen kasvun tulkinnat muissa tutkimuksissa

Toista tutkimuskysymystä, millaisia muita tulkintoja on löydettävissä puolisoaan hoitavan henkilöohtaisesta kasvusta, varten käytiin läpi tutkimukset, joissa kasvun kokemuksia ei arvioitu valmiilla mittareilla. Näistä tutkimuksista löydettyjen kategorioiden ryhmittelyn apuna käytettiin edellä mainittua PTGI-mittarin luokittelua.

Muissa tutkimuksissa trauman jälkeisen kasvun tunnistetut yläkategoriat olivat muun muassa ihmissuhteiden arvostaminen, uusien taitojen löytäminen, henkilökohtainen vahvistuminen, elämän merkityksellisyyden ymmärtäminen, elämän tavoitteiden muuttaminen, positiivisen näkökulman omaksuminen ja näkökulman muuttuminen kuolemaan. Niiden sisältöä kuvataan seuraavassa tarkemmin.

\section{Ihmissuhteiden arvostaminen}

Henkilökohtaisen kasvun kokemuksiin liitettiin kokemukset ihmissuhteiden merkityksellisyydestä, arvostamisesta ja tarpeellisuudesta. Omaishoivassa tämä saattoi ilmetä siten, että läheisen hyväksi tehtävät asiat, kuten hoivaaminen, koettiin arvokkaiksi ja tärkeiksi (Charlifue ym. 2016). Ihmissuhteiden merkityksellisyyttä ilmensi myös omaishoitajan halu selvittää menneitä ihmissuhdeongelmia (Tang 2018) sekä muiden ihmisten tarpeellisuuden havaitseminen. Samaa ulottuvuutta ilmensivät omaishoitajan kärsivällisyyden ja ymmärtäväisyyden lisääntyminen sekä suhteen parantuminen hoivaa tarvitsevaan läheiseen. Esimerkiksi dementoivaa sairautta sairastava läheinen saattaa kysellä toistuvasti asioita ja hänen toimintaansa on tarpeen ohjata koko ajan. Tämä vaatii paljon voimavaroja hoitavalta läheiseltä. Mikäli omaishoitaja jaksaa arvostaa läheistään hänen haastavasta käyttäytymisestään huolimatta tai mikäli hän ymmärtää sairauden syyksi käyttäytymisen muutoksiin, niin hänen on helpompi toimia ymmärtäväisesti näissä tilanteissa (Jewell ym. 2016; Lawson ym. 2018).

\section{Uusien taitojen löytäminen}

Henkilökohtaista kasvua kuvastivat avoimuus uusille asioille, uusiin haasteisiin vastaaminen ja uusien kiinnostuksen kohteiden kokeileminen ja vakiinnuttaminen elämässä (Hirooka ym. 2018b). Omaishoitajan selviytymistaidot saattoivat kohentua, kun hän kohtasi arjessa vastaan tulevia haasteita (Jewell ym. 2016). Läheisen toimintakyvyn muutoksen tai heikkenemisen seurauksena häntä hoitava puoliso joutuu usein opettelemaan uusia, aiemmin itselle tuntemattomia ja läheiselle kuuluneita taitoja. Esimerkiksi kodin remonttitehtävistä huolehtineen miehen sairastumisen tai vammautumisen seurauksena vaimo voi joutua opettelemaan ensimmäistä kertaa elämässään näitä taitoja ja omaksumaan uusi rooleja arjessa. Uusissa taidoissa ja rooleissa onnistuminen saattaa tuntua hyvältä ja voimaannuttavalta (Peacock ym. 2017).

\section{Henkilökohtainen vahvistuminen ja itsetuntemuksen lisääntyminen}

Kasvuun liitettiin myös henkilökohtainen vahvistuminen ja kasvanut voiman tunne, mitkä omaishoidossa liittyivät esimerkiksi siihen, että omaishoitaja selviytyi fyysisesti raskaasta hoivasta sekä hoivaan liittyvien päätösten tekemisestä (Peacock ym. 2017; myös Jewell ym. 2016; Stahl \& Schulz 2018). Esimerkiksi syöpään sairastuneen läheisen omaishoitaja saattoi löytää henkisen potentiaalinsa ja tunsi vahvistuvansa, kun hän kohtasi hoivassa eteen tulleita pelkoja ja sairastamiseen liittyviä vaikeita ja pelottavia asioita (Tang 2018; Hirooka ym. 2018b).

Vahvuutta ilmensi myös se, että hoitava puoliso auttoi sairastunutta kohtaamaan sairautensa (Peacock ym. 2017). Henkilökohtaiseen kasvuun liittyi myös lisääntyvä tietoisuus omasta itsestä (Jewell ym. 2016), mikä on tärkeää edellytys omaishoitajan hyvinvoinnille. 


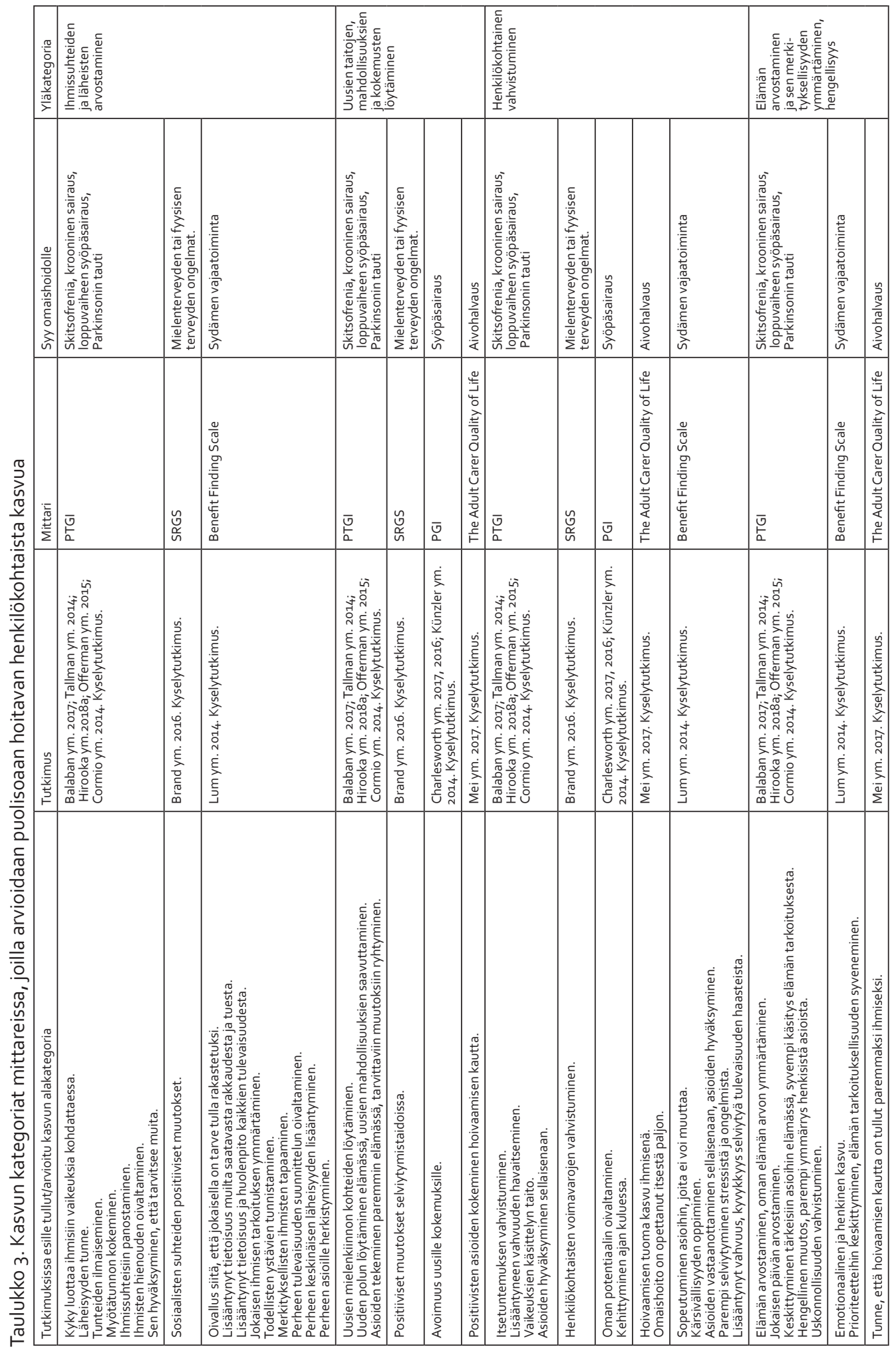




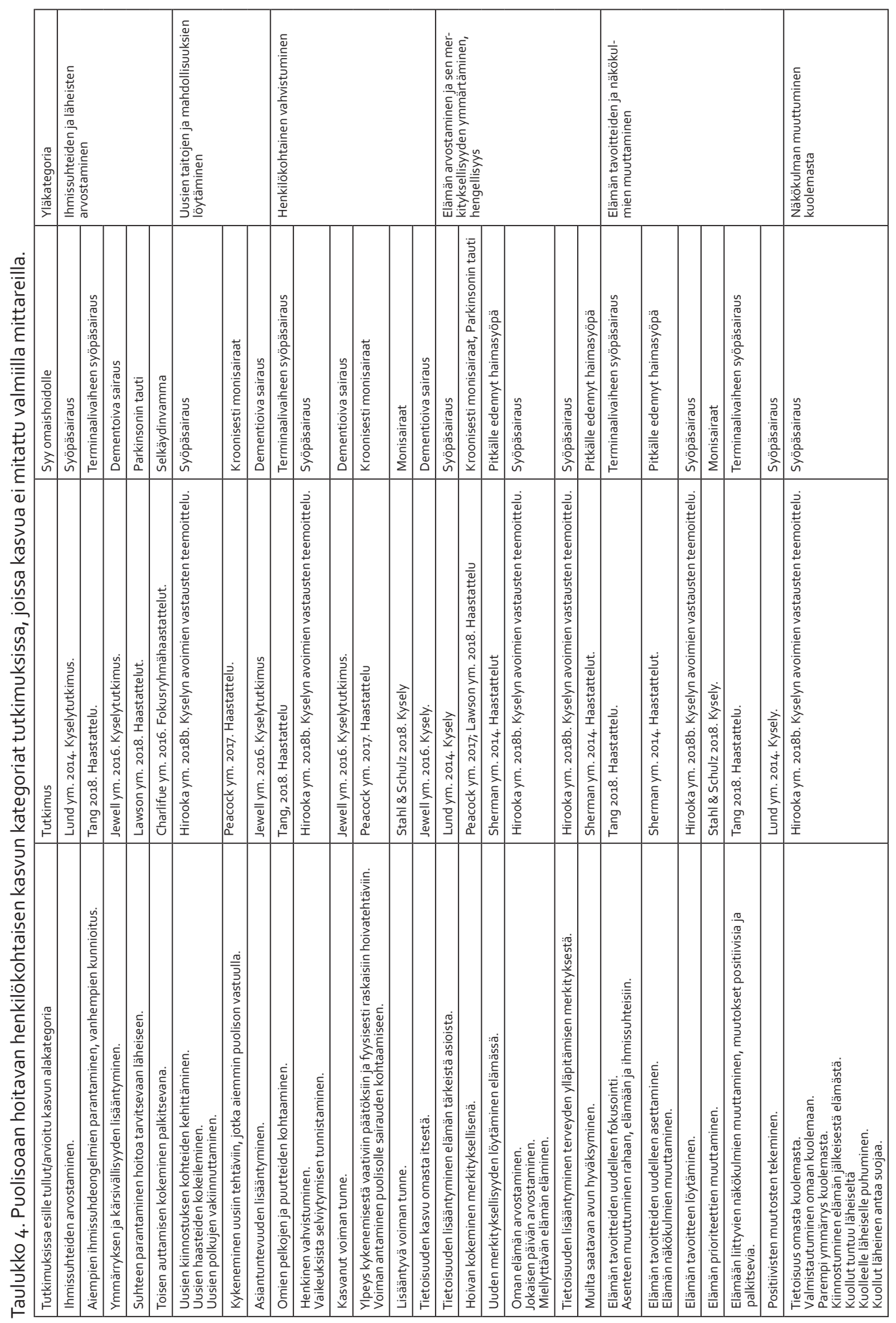




\section{Elämän arvostaminen ja sen merkityksellisyyden ymmärtäminen}

Lundin tutkimuksessa syöpäsairaan läheisen omaishoitajat kuvasivat tietoisuutensa lisääntyneen elämän tärkeistä asioista (Lund 2014). Mikäli omaishoitaja koki antamansa hoivan merkitykselliseksi, myös elämä tuntui merkitykselliseltä (Peacock ym. 2017; Lawson ym. 2018; Sherman ym. 2014). Elämän arvostamista kuvasi myös se, että omaishoitajan tietoisuus terveyden edistämisen merkityksestä lisääntyi (Hirooka ym. 2018b). Omaishoitajan oman elämän arvostuksen lisääntyminen näkyi siten, että hän suostui ottamaan vastaan ulkopuolista apua sen sijaan, että olisi sinnitellyt yksinään (Sherman ym. 2014).

\section{Elämän tavoitteiden muuttaminen, positiivisen näkökulman omaksuminen}

Katsauksen tutkimuksissa tuli esille muun muassa syöpään sairastuneiden henkilöiden omaishoitajien elämälle asetettujen tavoitteiden muuttuminen ja niiden uudelleen suuntaaminen (Tang 2018; Stahl \& Schulz 2018; Hirooka ym. 2018b). Omaishoidon vaativuuden myötä suhde koko elämään ja muun muassa rahaan ja ihmissuhteisiin saattoi muuttua (esim. Tang 2018). Elämään liittyvät näkökulmat saattoivat myös muuttua myös enemmän positiivisiksi ja palkitseviksi (Lund 2014; Tang 2018).

\section{Näkökulman muuttuminen kuolemasta}

Syöpäsairaiden henkilöiden omaishoitajien kohdalla omaishoitajan kokemaa henkistä kasvua saattoi Hirookan ja muiden (2018b) tutkimuksen mukaan ilmentää muuttunut näkökulma kuolemasta. Tämä tuli esille siten, että omaishoitaja pohti elämän jälkeistä aikaa ja oli siitä kiinnostunut. Myös tietoisuus omasta kuolemasta lisääntyi. Läheinen saattoi myös tuntua tutulta ja turvalliselta kuoleman jälkeen.

\section{Tutkimuksen rajoituksia}

Kirjallisuuskatsauksen laadun varmistamiseksi katsaukseen sisällytettiin ainoastaan vertaisarvioituja artikkeleita. Katsauksen artikkeleissa käytetyt analyysimenetelmät eivät olleet kriteereitä katsaukseen valinnalle, minkä vuoksi artikkelit sisälsivät erilaisia tutkimustapoja.

Toisessa tutkimuskysymyksessä, jossa kysyttiin millaisia muita tulkintoja on löydettävissä puolisoaan hoitavan henkilökohtaisesta kasvusta, aineistona olivat tutkimukset, joissa kasvua ei arvioitu erityisesti siihen muokatulla mittarilla (taulukko 4). Useassa näistä tutkimuksista aineisto kerättiin haastattelulla tai teemoittelemalla avoimien kysymysten vastaukset. Muutamissa tutkimuksissa käytettiin muita kuin kasvun mittareita ja saatuja tuloksia arvioitiin kasvun näkökulmasta (Lund 2014; Jewell 2016).

Useassa tutkimukseen valituissa artikkeleissa trauman jälkeistä kasvua mitattiin valmiilla mittarilla. Eniten käytetty mittari oli PTGI (Post Traumatic Growth Inventory), jolla kartoitetaan henkilöiden kokemia positiivisia muutoksia merkittävien stressitekijöiden jälkeen. Mittaria on arvosteltu siitä, että se ei kykene luomaan tarkkaa kuvaa trauman jälkeisestä kasvusta, koska vastatessaan henkilö muistelee jälkikäteen aiempiin traumaattisiin kokemuksiin liittyviä asioita (Minaudo 2017). Tämän ja muiden mittareiden ongelma on myös se, että vastausvaihtoehdot annetaan valmiina ja osa vastaajien kokemuksista jää havaitsematta.

Voidaankin arvella, että mittarit eivät tavoita kokonaisuudessaan kasvun käsitteen rikasta sisältöä. Tämän tutkimuksen aineistossa oli mukana myös sellaisia tutkimuksia, joissa ei käytetty valmiita mittareita kasvun arvioimiseen. Näin ollen puolisohoitajan kasvun käsitettä pystyttiin tarkastelemaan mittaritutkimuksia laajemmin sekä arvioimaan mahdollisia puuttuvia ulottuvuuksia.

Tämän katsauksen artikkelissa oli useita tutkimuksia, joissa hoitoa tarvitsevalla läheisellä oli pitkälle edennyt vakava sairaus kuten 
syöpä. Näistä tutkimuksista nousi esille myös omaishoitajan suhde kuolemaan. Syöpään sairastuminen voi muodostaa uhan elämän jatkumiselle ja uhka voi uusiutua, mikäli sairaus ei ole hoidettavissa. On ymmärrettävää, että näin haasteellisiin tilanteisiin on liitetty kasvun tutkimusta. Olisi kuitenkin kiinnostavaa laajentaa tutkimusaineistoa runsaammaksi myös muiden omaishoidon tilanteiden osalta, jotta olisi saatu monipuolisempaa kuvaa henkisestä kasvusta.

Alkuperäisenä tarkoituksena oli käyttää käsiteanalyysiä tutkimusmenetelmänä, mutta tutkimuksessa päädyttiin kuitenkin sisällönanalyysin tekemiseen. Tämä osoittautui tulokselliseksi, sillä tavoitteena oli erityisesti selvittää valitun käsitteen tulkintoja. Tähän tarkoitukseen sisällönanalyyttinen tarkastelu sopi hyvin, sillä sen avulla puolisohoitajan henkiseen kasvuun liittyvät teemat tarkentuivat ja jäsentyivät.

\section{Pohdintaa}

Puolison hoivaaminen voi tulla monen ikääntyvän henkilön eteen kumppanin sairastuessa vakavasti. Omaishoitotutkimus on nostanut esille omaishoitajan kokeman uupumuksen lisäksi myös hoivaamiseen liittyviä positiivisia kokemuksia, esimerkiksi kokemuksen henkilökohtaisesta kasvusta. Kirjallisuuskatsauksen perusteella henkilökohtainen kasvu puolisohoidossa ilmenee esimerkiksi ihmissuhteiden ja elämän arvostamisena, uusien taitojen löytämisenä ja henkilökohtaisena vahvistumisena. Ihmissuhteet tuntuvat entistä tärkeämmiltä ja merkityksellisemmiltä, mikä ilmenee myös myötätuntona muita kohtaan. Kasvu saattoi tulla esille myös elämälle asetettujen tavoitteiden muuttumisena sekä positiivisina hoivakokemuksina sekä elämään liittyvien positiivisten asioiden havaitsemisena. Kasvuun liittyy myös kokemus uusien asioiden ja taitojen oppimisesta, mikä vahvistaa luottamusta omaan selviytymiseen.

Henkilökohtainen kasvu yhdistetään haasteellisten tilanteiden läpi käymiseen liittyviin muutoksiin. Omaishoitotilanteisiin sisältyy monenlaisia elämän arkea ja jatkuvuutta haastavia tilanteita. Mikäli omaishoito jatkuu kauan, voivat nämä tilanteet uusiutua kerta toisensa jälkeen. Tätä haastavien tilanteiden toistumista voidaan pitää erityisesti omaishoidolle tyypillisenä piirteenä. Lisätutkimusta tarvittaisiin siitä, miten hoitajan kasvun kokemus mahdollisesti muuttuu haastavien tilanteiden toistuessa yhä uudelleen.

Katsauksessa esille tulleiden kasvun ulottuvuuksien jäsentelyssä käytettiin apuna PTGImittarin ulottuvuuksia. PTGI oli tutkimuksissa käytetyistä mittareista monipuolisin. Muut mittarit olivat suppeampia keskittyen kapeammalle alueelle kasvun kokemuksista. PTGImittarin ulottuvuudet tuntuivat sopivan jäsentelyn rungoksi ja runkoa täydennettiin mm. haastatteluiden ja kyselyn teemoittelusta saaduilla ulottuvuuksilla (mm. Tang 2018; Hirooka ym. 2018b; Sherman ym. 2014; Lund ym. 2014). Näitä olivat sellaiset ulottuvuudet kuten elämän tavoitteiden muuttaminen ja näkökulman muutokset suhteessa kuolemaan. Tätä voisi selittää sillä, että nähdessään läheltä elämän rajallisuuden omaishoitajan elämälle asetetut prioriteetit muuttuvat ja tavoitteiden asettamisen merkitys voimistuu. Tämä voi ilmetä myös positiivisen elämänasenteen vahvistumisena.

Aikaperspektiivin rajallisuus elämässä korostaa elämän prioriteettien merkitystä ja tavoitteiden asettamisen tärkeyttä. Kuoleman läheisyys voi muuttaa myös omaishoitajan kuolemasuhdetta sellaiseksi, että se ymmärretään jokaisen elämään kuuluvaksi. Näyttää siltä, että omaishoitajan kokemaan henkilökohtaiseen kasvuun liittyy uusia kategorioita, joita mittaritutkimuksissa ei esiintynyt. Näitä ovat konkreettiset muutokset siinä, mitä asioita elämässä tavoitellaan ja pidetään tärkeinä sekä miten kuolema koetaan. Saattaa olla, että PTGImittarin henkilökohtaista kasvun käsitettä pitäisikin laajentaa näillä puolison omaishoidossa esiin nousseilla kasvun ulottuvuuksilla.

Tätä tukee myös Tedeschin ja muiden (2017) tutkimus PTGI-mittarin laajentamisesta. Ky- 
seisen tutkimuksen kohderyhmänä oli opiskelijoita Turkista, Japanista ja Yhdysvalloista. Mittarin hengellisiä muutoksia käsittelevää ulottuvuutta laajennettiin tutkimuksessa eksistentiaalisilla osioilla. Tämä tapahtui lisäämällä PTGI-X:ksi nimettyyn mittariin muun muassa osio, joka käsitteli kykyä kohdata elämän ja kuoleman kysymyksiä. Samoin mittariin lisättiin kysymykset, jotka arvioivat vastaajan yhteyden kokemista kaikkeen olemassa olevaan sekä harmonian kokemista maailman kanssa.

Tässä tutkimuksessa tarkastelun kohteena olivat kasvun kokemusten tulkinnat kirjallisuudessa, mutta lisätutkimusta kaivataan erityisesti prosesseista ja keinoista, joiden kautta kasvun kokemuksia saavutetaan. Joissakin tutkimuksissa on todettu, että vakavasti sairastuneen kokemukset henkilökohtaisesta kasvusta ovat yhteydessä hänen puolisonsa kokemuksiin ja erityisesti puolison sairauteen kohdistamaan kognitiiviseen ja emotionaaliseen prosessointiin. Sairastuneet henkilöt kokivat enemmän kasvua silloin, kun läheiset puhuivat omista tunteistaan (vrt. Manne ym. 2004, 451-452). Yksi selitys tähän on se, että tunteista puhuva läheinen kannustaa avoimeen kommunikaatioon ja sairastuneen on vaivattomampi puhua huolen aiheistaan, mikä tukee hänen mahdollisuuksiaan saavuttaa kasvun kokemuksia. Olisi tärkeä myös tarkastella tutkimuksen keinoin, mikä merkitys surulla ja luopumisella ja niiden

\section{Kirjallisuus}

Autio, T. (2014). Puolisoaan hoitavien tunteet omaishoitajakertomusten valossa. Lisensiaatintutkimus. Sosiaalipedagogiikka, Yhteiskuntatieteiden ja kauppatieteiden tiedekunta. Kuopio: Itä-Suomen yliopisto.

Autio, T. \& Rissanen, S. (2018). Positive emotions in caring for a spouse: a literature review. Scandinavian Journal of Caring Sciences, 32 (1), 45-55. doi: 10.1111/scs.12452. Epub 2017 May 24.

Balaban, O. D., Yazar, M. S., Aydin, E., Agachanli, R. \& Yumrukcal, H. (2017). Posttraumatic growth läpikäymisellä on henkilökohtaisen kasvun kokemuksille. Tämänkaltaisen tutkimuksen pohjalta voitaisiin suositella keinoja, joiden avulla on mahdollista tukea omaishoitajia käymään läpi haasteellisia elämänvaiheita ja -tilanteita.

Omaishoitajat huolehtivat monen ikääntyneen henkilön hyvinvoinnista ja arjen sujumisesta ja siten heillä on merkittävä sekä eettinen että taloudellinen rooli osana yhteiskunnan palvelujärjestelmää. Omaishoito vähentää sosiaali- ja terveydenhuollon palvelujärjestelmän kustannuksia, vaikka palvelujärjestelmä pyrkii myös osin tukemaan omaishoitajia ja heidän läheisiään sekä palveluin että taloudellisilla tulonsiirroilla. Kasvun kokemukset auttavat omaishoitajaa jaksamaan haastavassa elämäntilanteessa ja toimivat mielenterveyttä ennakoivasti tukevana elementtinä. Näiden kokemusten saavuttaminen ei kuitenkaan ole itsestäänselvyys ja on tärkeää ymmärtää, millaiset palvelut ja kohtaamiset auttavat niiden saavuttamisessa. Tällä hetkellä kasvun kokemuksen merkitystä ei tunnisteta riittävästi omaishoitoon suuntautuvien palvelujen ja tuen sisällöissä.

\section{Yhteydenotto}

Tiina Autio, YTL, KM, LuK

Pääkaupunkiseudun sosiaalialan osaamiskeskus Socca

tiina.autio@hus.fi

and its correlates in primary caregivers of schizophrenic patients. Indian Journal of Psychiatry, 59 (4), 442-450.

doi: 10.4103/psychiatry.IndianJPsychiatry_18_17.

Brand, C., Barry, L. \& Gallagher, S. (2016). Social support mediates the association between benefit finding and quality of life in caregivers. Journal of Health Psychology, 21 (6), 1126-1136. doi: 10.1177/1359105314547244. 
Cadell, S. (2007). The Sun Always Comes Out after It Rains: Understanding Posttraumatic Growth in HIV Caregivers. Health E Social Work, 32 (3), 169-176. https://doi.org/10.1093/hsw/32.3.169.

Charlesworth, G., Sinclair, J. B., Brooks, A., Sullivan, T., Ahmad, S. \& Poland, F. (2017). The impact of volunteering on the volunteer: findings from a peer support programme for family carers of people with dementia. Health and Social Care Health in the Community, 25 (2), 548-558. doi: 10.1111/hsc.12341.

Charlesworth, G., Burnell, K., Crellin, N., Hoare, Z., Hoe, J., Knapp, M., Russell, I., Wenborn, J., Woods, B. \& Orrell, M. (2016). Peer support and reminiscence therapy for people with dementia and their family carers: a factorial pragmatic randomised trial. Journal of Neurology, Neurosurgery E Psychiatry, 87 (11), 1218-1228. doi: 10.1136/jnnp-2016-313736.

Charlifue, S. B., Botticello, A., Kolakowsky-Hayner, S. A., Richards, J. S. \& Tulsky, D. S. (2016). Family caregivers of individuals with spinal cord injury: exploring the stresses and benefits. Spinal Cord, 54 (9), 732-736. doi: 10.1038/sc.2016.25.

Chinn, P. L. \& Jacobs, M. K. (1992). A Model for Theory Development in Nursing. Teoksessa Nicoll, L. H. (toim.), Perspectives on Nursing Theory (s. 391-398). Philadelphia: J. B. Lippincott Company.

Cormio, C., Romito, F., Viscanti, G., Turaccio, M., Lorusso, V. \& Mattioli, V. (2014). Psychological well-being and posttraumatic growth in caregivers of cancer patients. Frontiers in Psychology, 5, 1342. doi:10.3389/fpsyg.2014.01342.

Elo, S. \& Kyngäs, S. H. (2008) The qualitative content analysis process. Journal of Advanced Nursing, 62 (1), 107-115.

Findler, L., Dayan-Sharabi, M. \& Yaniv, I. (2014). The Overlooked Side of the Experience: Personal Growth and Quality of Life Among Grandparents of Children Who Survived Cancer. Journal of Family Social Work, 17 (5), 418-437. doi: 10.1080/10522158.2014.945675.

Folkman, S. (2008). The case for positive emotions in the stress process. Anxiety, Stress Coping, 21, 3-14.

Fredrickson, B. L. (2001). The role of positive emotions in positive psychology: the broaden-andbuild theory of positive emotions. American Psychologist, 56 (3), 218-226. https://doi.org/10.1037/0003-066X.56.3.218.
Fredrickson, B. L. \& Cohn, M. A. (2010). Positive emotions. Teoksessa Lewis M., Haviland-Jones, J. M. \& Barrett, L.F. (toim.) Handbook of emotions (s. 777-797). New York: Guilford Press.

Gottlieb, B. H. \& Wolfe, J. (2002). Coping with family caregiving to persons with dementia: a critical review. Aging and Mental Health, 6 (4), 325-342. doi: 10.1080/1360786021000006947.

Hamana, L. \& Sharon, M. (2013). Posttraumatic Growth and Subjective Well-Being among Caregivers of Chronic Patients: A Preliminary Study. Journal of Happiness Studies, 14 (6), 1717-1737. doi: 10.1007/s10902-012-9405-8.

Hirooka, K., Fukahori, H., Taku, K., Togari, T. \& Ogawa, A. (2018a). Examining Posttraumatic Growth Among Bereaved Family Members of Patients With Cancer Who Received Palliative Care at Home. American Journal of Hospice E Palliative Medicine, 35 (2), 211-217. doi:10.1177/1049909117703358.

Hirooka, K., Fukahori, H., Taku, K., Izawa, S. \& Ogawa, A. (2018b). Posttraumatic growth in bereaved family members of patients with cancer: a qualitative analysis. Supportive Care in Cancer, Epub. August. doi: 10.1007/s00520-018-4440-6. Jacobs, M. K. \& Huether, S. E. (1992). Nursing Science: The Theory-Practice Linkage. Teoksessa Nicoll L. H. (toim.), Perspectives On Nursing Theory (520-528). Philadelphia: J.B. Lippincott Company.

Jewell, A., Cole, J., Rolph, J. \& Rolph, P. (2016). The faith of primary carers of persons with dementia, Journal of Religion, Spirituality \& Aging, 28 (4), 313-337. doi: 10.1080/15528030.2016.1193098.

Kashdan, T. \& Biswas-Diener, R. (2015). The Upside of Your Dark Side. New York: Plume Books.

Kling, K. C., Malick-Seltzer, M., \& Ryff, C. D. (1997). Distinctive late-life challenges: Implications for coping and well-being. Psychology and Aging, 12 (2), 288-295.

Künzler, A., Nussbeck, F. W., Moser, M. T., Bodenmann, G. \& Kayser, K. (2014). Individual and dyadic development of personal growth in couples coping with cancer. Supportive Care in Cancer, 22, 53-62. doi: 10.1007/s00520-013-1949-6.

Lazarus, R. \& Folkman, S. (1984). Stress, Appraisal, and Coping. New York: Springer.

Lawson, R. A., Collerton, D., Taylor, J.-P., Burn, D. J. \& Brittain, K. R. (2018). Coping with Cognitive Impairment in People with Parkinson's Disease 
and Their Carers: A Qualitative Study. Parkinson's Disease, Vol. 2018, Article ID 1362053. doi: 10.1155/2018/1362053.

Lum, H. D., Lo, D., Hooker, S. \& Bekelman, D. B. (2014). Caregiving in heart failure: Relationship quality is associated with caregiver benefit finding and caregiver burden. Heart \& Lung, 43 (4), 306-310. doi: 10.1016/j.hrtlng.2014.05.002.

Lund, L., Ross, L., Petersen, M. A. \& Groenvold, M. (2014). Cancer caregiving tasks and consequences and their associations with caregiver status and the caregiver's relationship to the patient: a survey. BMC Cancer, 14, 541. doi: 10.1186/1471-2407-14-541.

Lämsä, A. M. \& Takala, T. (2004). Tulkitseva käsitetutkimus. Haettu 18.9.2019: https://metodix. fi/2014/05/19/lamsa-tulkitseva-kasitetutkimus/.

Mackenzie, A. \& Greenwood, N. (2012). Positive experiences of caregiving in stroke: a systematic review. Disability and Rehabilitation, 34 (17), 14131422. doi: 10.3109/09638288.2011.650307.

Manne, S., Ostroff, J., Winkel, G., Goldstein, L., Fox, K. \& Grana, G. (2004). Posttraumatic growth after breast cancer: patient, partner, and couple. Psychosomatic Medicine, 66 (3), 442-454. doi: 10.1097/01.psy.0000127689.38525.7d.

McLennon, S. M., Habermann, B. \& Rice, M. (2011). Finding meaning as a mediator of burden on the health of caregivers of spouses with dementia. Aging and Mental Health, 15 (4), 522-530. doi: 10.1080/13607863.2010.543656.

Mei, Y., Lin, B., Li, Y., Ding, C. \& Zhang, Z. (2017). Validity and reliability of Chinese version of Adult Carer Quality of Life questionnaire (ACQoL) in family caregivers of stroke survivors, PLOS ONE, November 13, 12 (11), e0186680. doi: 10.1371/journal.pone.0186680.

Minaudo, N. (2017). Book Review: Eranda Jayawickreme \& Laura E. R. Blackie: Exploring the Psychological Benefits of Hardship: A Critical Reassessment of Posttraumatic Growth. Journal of Youth and Adolescence, 46, 2387-2390.

Montgomery, R. J. V. \& Williams, K. N. (2001). Implications of differential impacts of care-giving for future research on Alzheimer care. Aging and Mental Health, 5 Suppl 1, S23-34.

Mullan, J. T. (1992). The bereaved caregiver: A prospective study of changes in well-being. The Gerontologist, 32 (5), 673-683.

doi:10.1093/geront/32.5.673.
Noyes, B. B., Hill, R. D., Hicken, B. L., Luptak, M., Rupper, R., Dailey, N. K. \& Bair, B. D. (2010). The role of grief in dementia caregiving. American Journal of Alzheimer's Disease and Other Dementias, 25 (1), 9-17. doi: 10.1177/1533317509333902.

Noro, A. (toim.) (2019). Omais- ja perhehoidon kehitys vuosina 2015-2018. Päätelmät ja suositukset jatkotoimenpiteiksi. Sosiaali- ja terveysministeriön raportteja ja muistioita 2018:61. Saatavilla http://julkaisut.valtioneuvosto.fi/ bitstream/handle/10024/161377/R_61_2018_ OMPE_11022019.pdf?sequence $=1 \&$ is Allowe$\mathrm{d}=\mathrm{y}$.

Offerman, M. P. J., Pruyn, J. F. A., de Boer, M. F., Busschbach, J. J. V. \& Baatenburg de Jong, R. J. (2015). Psychosocial consequences for partners of patients after total laryngectomy and for the relationship between patients and partners. Oral Oncology, 51 (4), 389-398. doi: 10.1016/j.oraloncology.

Ott, C. H., Sanders, S. \& Kelber, S. T. (2007). Grief and Personal Growth Experience of Spouses and Adult-Child Caregivers of Individuals with Alzheimer's Disease and Related Dementias. The Gerontologist, 47 (6), 798-809. doi: 10.1093/geront/47.6.798.

Park, C. L., Cohen, L. H. \& Murch, R. L. (1996). Assessment and Prediction of Stress-Related Growth. Journal of Personality, 64 (1), 71-105. doi: 10.1111/j.1467-6494.1996.tb00815.x.

Peacock, S., Sethi, B., Williams, A., Duggleby, W., Bayly, M., Swindle, J., Ploeg, J. \& Markle-Reid, M. (2017). Older Adult Spouses with Multiple Chronic Conditions: Challenges, Rewards, and Coping Strategies. Canadian Journal on Aging / La Revue canadienne du vieillissement, 36 (2), 209-222. doi: 10.1017/S0714980817000095.

Pearlin, L. I., Mullan, J. T., Semple, S. J. \& Skaff, M. M. (1990). Caregiving and the stress process: an overview of concepts and their measures. Gerontologist, 30 (5), 583-594. doi: 10.1093/geront/30.5.583.

Puusa, A. (2008). Käsiteanalyysi tutkimusmenetelmänä. Premissi.Haettu verkosta 19.9.2019: https://www. academia.edu/3310906/K\%C3\%A4siteanalyysi_ tutkimusmenetelm\%C3\%A4n\%C3\%A4.

Quinn, C., Clare, L. \& Woods, R. T. (2010). The impact of motivations and meanings on the wellbeing of caregivers of people with dementia: a systematic review. International Psychogeriatrics, 
22 (1), 43-55.

doi: $10.1017 / \mathrm{S} 1041610209990810$.

Rodgers, B. L. (1989). Concepts, analysis and the development of nursing knowledge: the evolutionary cycle. Journal of Advanced Nursing, 14 (4), 330-335.

doi: 10.1111/j.1365-2648.1989.tb03420.x.

Seligman, M. E. P. (2002). Authentic Happiness: Using the New Positive Psychology to Realize Your Potential for Lasting Fulfillment. New York: Free Press.

Seligman, M.E. P. (2011). Flourish: A Visionary New Understanding of Happiness and Wellbeing. New York: Free Press.

Sherman, D. W., McGuire, D. B., Free, D. \& Cheon, J. Y. (2014). A Pilot Study of the Experience of Family. Journal of Pain and Symptom Management, 48 (3), 385-399.

doi: 10.1016/j.jpainsymman.2013.09.006.

Stahl, S. T. \& Shulz, R. (2018). Restorative activities among bereaved caregivers of nursing home patients. Geriatric Nursing, 39 (4), 414-418. doi: 10.1016/j.gerinurse.2017.12.014.

Tallman, B. A., Lohnberg, J., Yamada, T. H., Halfdanarson, T. R. \& Altmaier, E. M. (2014). Anticipating Posttraumatic Growth from Cancer: Patients' and Collaterals' Experiences. Journal of
Psychosocial Oncology, 32 (3), 342-358.

doi: 10.1080/07347332.2014.897291.

Tang, Y. (2018). Challenges, personal growth and social support among family caregivers of terminally ill cancer patients in Southern China. Qualitative Social Work, Article first published online: February 2, 2018. doi: 10.1177/1473325018755890.

Tedeschi, R. G., Cann, A., Taku, K., Senol-Durak, E. \& Calhoun, L. G. (2017). The Posttraumatic Growth Inventory: A Revision Integrating Existential and Spiritual Change. Journal of Traumatic Stress, 30 (1), 11-18. doi: $10.1002 /$ jts. 22155 .

Tedeschi, R. G. \& Calhoun, L. (2004). Posttraumatic Growth: A New Perspective on Psychotraumatology. Psychiatric Times, 21 (4), 58-60.

Tedeschi, R. G. \& Calhoun, L. G. (1996). The Posttraumatic Growth Inventory: Measuring the Positive Legacy of Trauma. Journal of Traumatic Stress, 9 (3), 455-471. doi: $10.1002 /$ jts. 2490090305 .

Tuomi, J. \& Sarajärvi, A. (2003). Laadullinen tutkimus ja sisällönanalyysi. Helsinki: Tammi.

Walker, L. O. \& Avant, K. C. (2005). Strategies for Theory Construction in Nursing. 4. painos. New Yersey: Prentice Hall. 